\title{
There is no relationship between SOD2 Val-16Ala polymorphism and breast cancer risk or survival
}

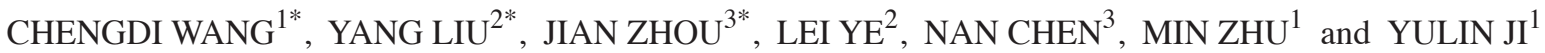 \\ Departments of ${ }^{1}$ Respiratory and Critical Care Medicine, ${ }^{2}$ Vascular Surgery and ${ }^{3}$ Thoracic Surgery, West China \\ Medical School/West China Hospital, Sichuan University, Chengdu, Sichuan 610041, P.R. China
}

Received January 21, 2017; Accepted July 21, 2017

DOI: $10.3892 / \mathrm{mco} .2017 .1376$

\begin{abstract}
Breast cancer is the most common diagnosed cancer among females worldwide. Superoxide dismutase 2 (SOD2), an antioxidant enzyme, may break the balance between the oxidant and antioxidant system to induce various diseases. The present study aimed to clarify the association between the SOD2 Val-16Ala polymorphism and breast cancer risk or survival. Thus, a meta-analysis of the relevant articles retrieved from PubMed and EMBASE databases was conducted to illuminate the association with odd ratios (ORs) or hazards ratios (HRs). A total of 26 eligible publications $(n=38,008)$ were available in risk analysis and eight publications $(n=5,746)$ in survival analysis. The results demonstrated a marginal association between breast cancer risk and SOD2 polymorphism in Caucasian patients [TT vs. CT + CC: (OR, 0.94; 95\% confidence interval (CI), 0.88-1.00)]. However, no other positive results were observed in risk and survival of breast cancer in the whole study [T vs. C: (OR, 0.99; 95\% CI, 0.96-1.02); CT vs. CC: (OR, 1.00; 95\% CI, 0.95-1.05); TT vs. CC: (OR, 0.98; 95\% CI, 0.92-1.05); TT vs. CT + CC: (OR, 1.00; 95\% CI, 0.95-1.05); CT + TT vs. CC: (OR, 0.99; 95\% CI, 0.95-1.05)]. The present meta-analysis indicated that there was no significant relationship between SOD2 Val-16Ala polymorphism and breast cancer risk or survival, although in Caucasian patients, the SOD2 TT genotype may marginally decrease the risk of breast cancer in comparison to the $\mathrm{CT}+\mathrm{CC}$ genotype.
\end{abstract}

Correspondence to: Professor Yulin Ji, Department of Respiratory and Critical Care Medicine, West China Medical School/West China Hospital, Sichuan University, 37 Guo Xue Xiang, Chengdu, Sichuan 610041, P.R. China

E-mail: jiyulinscu@sina.cn

*Contributed equally

Abbreviations: SOD, superoxide dismutase; OR, odds ratio; HR, hazards ratio; ROS, reactive oxygen species; CI, confidence interval; SNP, single nucleotide polymorphism

Key words: SOD2, Val-16Ala, breast cancer, risk, survival, meta-analysis

\section{Introduction}

Breast cancer, diagnosed in $~ 1.7$ million patients and being the cause of 521,900 mortalities in 2012, is the most common diagnosed cancer and the most notable cause of cancer mortality among females worldwide (1). Various factors have an impact in the incidence of breast cancer, such as family history, gene susceptibility, hormone, diet, lifestyle factors and environmental exposures (2-6).

Increasing research has identified a significant effect of reactive oxygen species (ROS) in breast cancer etiology (7-12). ROS may induce oxidative stress, resulting in DNA sequence changes and damage, such as mutations, rearrangements and DNA strand breaks. ROS may also lead to damage to lipids, proteins, membranes and mitochondria $(8,13)$. In humans, various antioxidant actions may balance the effect of ROS, including antioxidant enzymes and antioxidant agents. Antioxidant enzymes predominantly include glutathione peroxidase, catalase and, most importantly, superoxide dismutase (SOD) $(7,8)$.

There are three types of SOD, which are cytosolic $\mathrm{Cu}-\mathrm{ZnSOD}$ (SOD1), extracellular Cu-ZnSOD (SOD3) and mitochondrial SOD (SOD2; MnSOD). SOD2 is mostly produced in mitochondria, having a vital effect on balancing mitochondrial oxidant stress and antioxidant defense (14). SOD2 gene, located on 6q25 of chromosome 6, encodes SOD2, whose expression is highly regulated at transcription, translation and posttranslational levels (15-17). SOD2, a polymorphic enzyme, has several structural mutations and single nucleotide polymorphisms (SNPs). The most common SNP is rs4880 SNP, also called rs1799725 SNP, which is a T to C substitution in exon 2, changing the amino acid codon at position 16 from valine to alanine, known as the SOD2 Val-16Ala genotype and also as Ala-9Val as the SNP is 9 amino acids upstream of the cleavage site (18-20).

According to the latest research, various studies have demonstrated an association between the polymorphism of SOD2 and disease, particularly between SOD2 Val-16Ala and cancer. Several meta-analyses have demonstrated that the SOD2 Val-16Ala SNP polymorphism increases susceptibility to various types of cancer, such as prostate cancer (21-23), lung cancer, colorectal cancer and non-Hodgkin lymphoma (24). However, referring to breast cancer, from 1999 to present, there have been many studies and cohorts to investigate the 


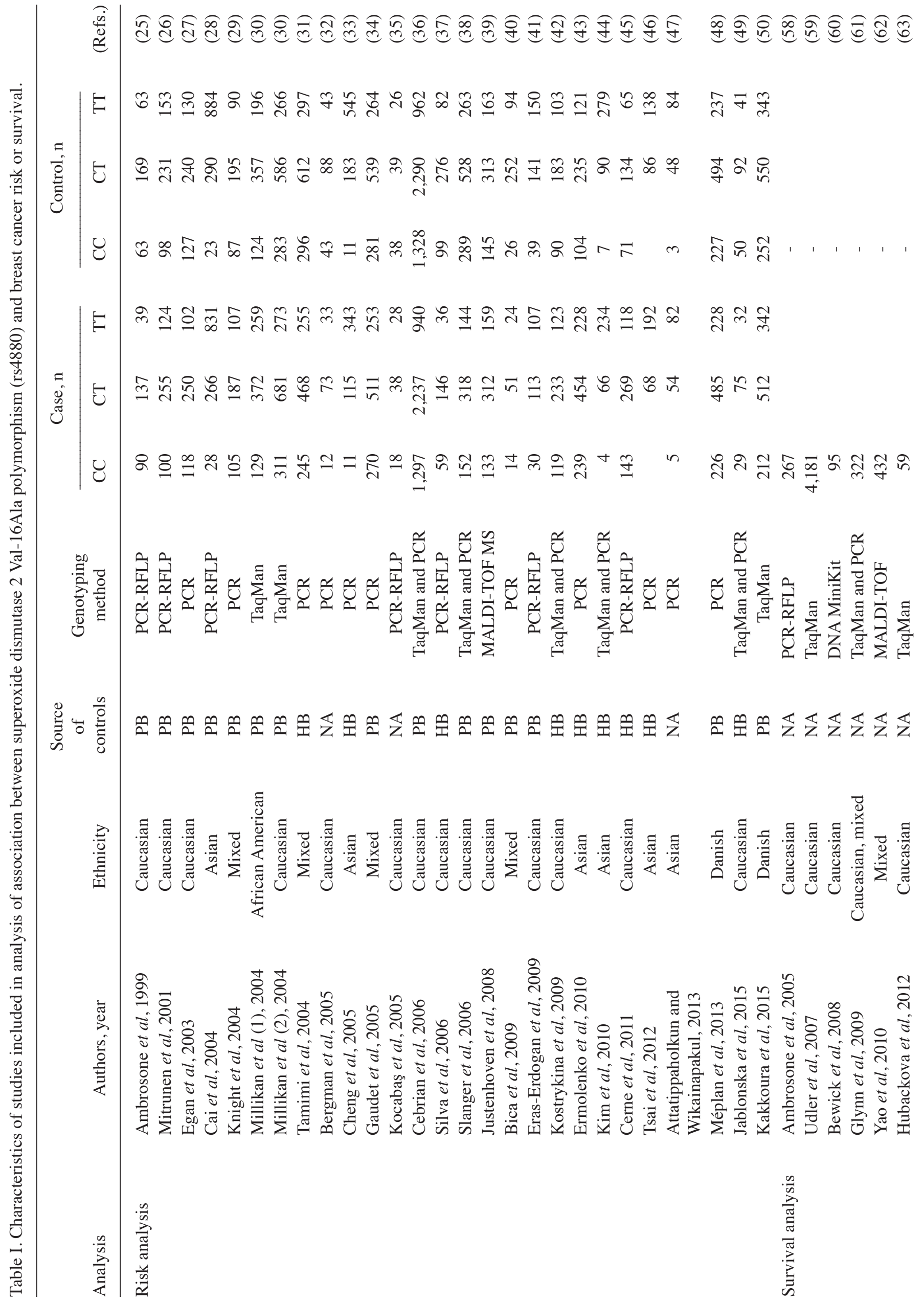




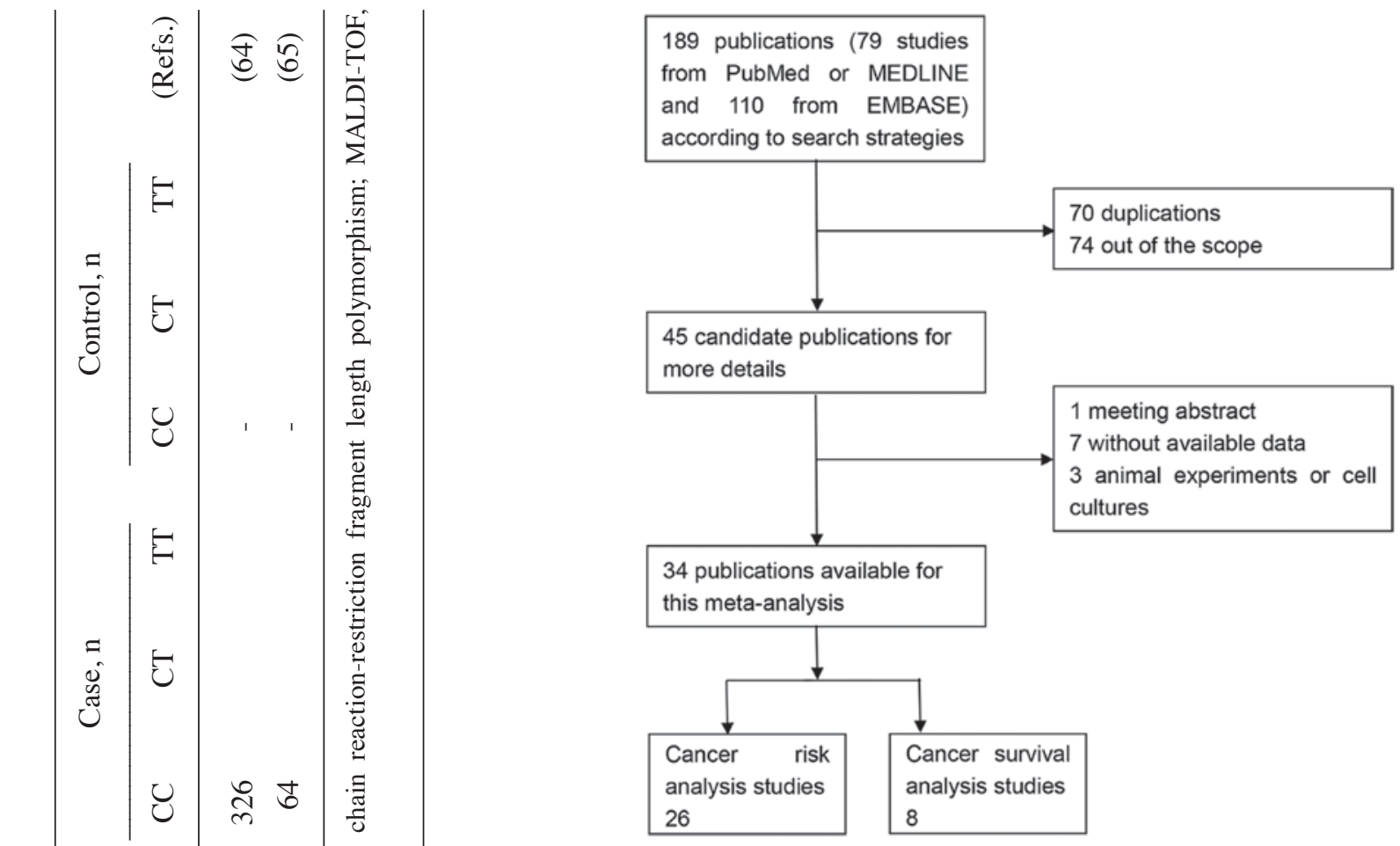

Figure 1. Flow chart of the literature search and selection of included studies.

relationship between SOD2 Val-16Ala polymorphism and breast cancer; however, these studies cannot reach an agreement and have drawn some conflicting conclusions (25-50). In 2008, the first meta-analysis to investigate the association between Val-16Ala and breast cancer was conducted, with 13 publications including a total of 7,366 cases and 9,102 controls; however, it indicated no overall association with the Val-16Ala polymorphism (51). Subsequently, from 2010-2012, four meta-analyses also demonstrated similar negative effects (52-55). Presently, due to increased individual studies and larger sample sizes, a more accurate estimation may be obtained to judge this association. Thus, an updated meta-analysis was performed to investigate whether SOD2 Val-16Ala polymorphism is a risk factor and/or prognostic factor for breast cancer.

\section{Materials and methods}

Search strategy. A comprehensive strategy was used to search PubMed (ncbi.nlm.nih.gov/pubmed) or MEDLINE (medline .com) and EMBASE (embase.com) to obtain the relevant publications about the association between breast cancer risk and SOD2 gene polymorphism. The search terms were 'superoxide dismutase 2,' 'SOD2,' 'MnSOD,' 'ala9val,' 'val16ala,' 'breast cancer,' 'breast carcinoma,' 'breast tumor,' 'breast neoplasm,' 'mammary cancer,' 'polymorphism,' 'mutation' and 'variant,' alone or in combination. The last updated data was October 5, 2016, and with no restriction of the post time. Additional publications listed in references were also retrieved by a computer-aided manual search to gain more information about this field. Furthermore, only publications in the English language were included in the meta-analysis. 
Table II. Summary of the included studies in the risk analysis regarding the ethnicity of patients.

\begin{tabular}{|c|c|c|c|c|c|c|c|c|}
\hline Polymorphisms & Ethnicity & $\begin{array}{c}\text { Studies, } \\
\mathrm{n}\end{array}$ & $\begin{array}{l}\text { Participants, } \\
\mathrm{n}\end{array}$ & $\begin{array}{l}\text { Odds } \\
\text { ratio }\end{array}$ & $\begin{array}{c}95 \% \\
\text { confidence } \\
\text { interval }\end{array}$ & P-value & $\begin{array}{l}\text { Egger's } \\
\text { value }\end{array}$ & $\begin{array}{l}\text { Begg's } \\
\text { value }\end{array}$ \\
\hline \multirow[t]{6}{*}{ T vs. C } & Caucasian & 14 & 20,589 & 0.98 & $0.94-1.02$ & 0.357 & & \\
\hline & Asian & 5 & 5,867 & 0.95 & $0.87-1.05$ & 0.319 & & \\
\hline & Danish & 2 & 4,108 & 1.04 & $0.95-1.13$ & 0.388 & & \\
\hline & African American & 1 & 1,437 & 1.14 & $0.98-1.32$ & 0.080 & & \\
\hline & Mixed & 4 & 55,23 & 1.00 & $0.93-1.08$ & 0.971 & & \\
\hline & Total & 26 & 37,524 & 0.99 & $0.96-1.02$ & 0.702 & 0.612 & 0.865 \\
\hline \multirow[t]{6}{*}{ CT vs. CC } & Caucasian & 14 & 15,821 & 1.03 & $0.97-1.10$ & 0.351 & & \\
\hline & Asian & 5 & 2,236 & 0.82 & $0.65-1.03$ & 0.089 & & \\
\hline & Danish & 2 & 2,958 & 1.05 & $0.89-1.22$ & 0.574 & & \\
\hline & African American & 1 & 982 & 1.00 & $0.75-1.33$ & 0.991 & & \\
\hline & Mixed & 4 & 4,139 & 0.90 & $0.79-1.03$ & 0.136 & & \\
\hline & Total & 26 & 26,136 & 1.00 & $0.95-1.05$ & 0.961 & 0.523 & 0.810 \\
\hline \multirow[t]{6}{*}{ TT vs. CC } & Caucasian & 14 & 10,142 & 0.97 & $0.89-1.05$ & 0.409 & & \\
\hline & Asian & 5 & 4,066 & 0.80 & $0.62-1.03$ & 0.090 & & \\
\hline & Danish & 2 & 2,067 & 1.08 & $0.91-1.29$ & 0.386 & & \\
\hline & African American & 1 & 708 & 1.27 & $0.93-1.73$ & 0.129 & & \\
\hline & Mixed & 4 & 2,708 & 0.99 & $0.85-1.15$ & 0.850 & & \\
\hline & Total & 26 & 19,691 & 0.98 & $0.92-1.05$ & 0.601 & 0.440 & 0.514 \\
\hline \multirow[t]{6}{*}{ TT vs. $\mathrm{CT}+\mathrm{CC}$} & Caucasian & 14 & 20,589 & 0.94 & $0.88-1.00$ & 0.059 & & \\
\hline & Asian & 6 & 6,351 & 1.03 & $0.92-1.16$ & 0.558 & & \\
\hline & Danish & 2 & 4,108 & 1.05 & $0.91-1.20$ & 0.505 & & \\
\hline & African American & 1 & 1,437 & 1.27 & $1.01-1.59$ & 0.037 & & \\
\hline & Mixed & 4 & 5,523 & 1.07 & $0.94-1.21$ & 0.312 & & \\
\hline & Total & 27 & 38,008 & 1.00 & $0.95-1.05$ & 0.954 & 0.755 & 0.904 \\
\hline \multirow[t]{6}{*}{$\mathrm{CT}+\mathrm{TT}$ vs. $\mathrm{CC}$} & Caucasian & 14 & 21,068 & 1.01 & $0.95-1.08$ & 0.742 & & \\
\hline & Asian & 5 & 5,867 & 0.82 & $0.65-1.02$ & 0.073 & & \\
\hline & Danish & 2 & 4,108 & 1.06 & $0.91-1.23$ & 0.456 & & \\
\hline & African American & 1 & 1,437 & 1.10 & $0.84-1.44$ & 0.505 & & \\
\hline & Mixed & 4 & 5,523 & 0.93 & $0.82-1.06$ & 0.280 & & \\
\hline & Total & 26 & 37,524 & 0.99 & $0.95-1.05$ & 0.839 & 0.737 & 0.261 \\
\hline
\end{tabular}

Inclusion and exclusion criteria. In the present meta-analysis, eligible publications had to be randomized controlled trials, cohort studies or case-control studies that investigated the association between breast cancer and SOD2 gene polymorphism. The publications meeting the following inclusion criteria were retained: i) The cases were diagnosed with breast cancer that was pathologically confirmed and the controls were free of breast cancer; ii) had sufficient data, such as size of the sample, alleles and genotypes, to calculate the odd ratios (ORs) or hazards ratios (HRs) with 95\% confidence intervals (95\% CIs); and iii) preferably used subgroup analysis. The exclusion criteria were as follows: i) Studies had no control individuals; ii) studies were about the activity of the SOD2 enzyme; iii) the study was not about the rs4880 or rs1799725 SNP. If there were some duplicated publications, the latest studies were retained. If several different publications had the same patient source, the studies with the largest number of individuals were reserved. Furthermore, two cooperators reviewed the publications independently to ensure that the appropriate studies were chosen.
Data extraction. Available data were extracted and collected by two investigators independently from all of the included publications, following the same standard protocol. If there were any inconsistencies between the data obtained by the two reviewers, the problem was solved through a careful discussion. If an agreement could not be reached, a third reviewer would take part in this to make everyone satisfied. Data information from the publications were about the first author, publish year, ethnicity, sources of controls, genotyping methods, total number of cases and controls, distribution of alleles and genotypes and the HR with $95 \%$ confidence interval (CI) of relative polymorphism.

Statistical analysis. The crude ORs with 95\% CIs for alleles and genotypes were used to estimate the association between breast cancer risk and SOD2 gene polymorphism, and HRs with $95 \%$ CIs were used for survival analysis. The pooled ORs and HRs were calculated for the genotypes of T vs. C, CT vs. CC, TT vs. CC, TT vs. CT + CC and CT + TT vs. CC, 
Table III. Summary of the included studies in the risk analysis regarding the menopausal status of patients.

\begin{tabular}{|c|c|c|c|c|c|c|c|c|}
\hline Polymorphisms & $\begin{array}{c}\text { Menopausal } \\
\text { status }\end{array}$ & $\begin{array}{l}\text { Studies, } \\
\mathrm{n}\end{array}$ & $\begin{array}{c}\text { Participants, } \\
\mathrm{n}\end{array}$ & $\begin{array}{l}\text { Odds } \\
\text { ratio }\end{array}$ & $\begin{array}{c}95 \% \\
\text { confidence } \\
\text { interval }\end{array}$ & P-value & $\begin{array}{l}\text { Egger's } \\
\text { value }\end{array}$ & $\begin{array}{l}\text { Begg's } \\
\text { value }\end{array}$ \\
\hline \multirow[t]{2}{*}{ T vs. C } & Premenopausal & 8 & 3,962 & 0.93 & $0.85-1.01$ & 0.095 & 0.138 & 0.101 \\
\hline & Postmenopausal & 9 & 6,182 & 0.97 & $0.90-1.04$ & 0.417 & 0.404 & 0.341 \\
\hline \multirow[t]{2}{*}{ CT vs. CC } & Premenopausal & 8 & 2,924 & 0.94 & $0.80-1.10$ & 0.419 & 0.621 & 0.566 \\
\hline & Postmenopausal & 9 & 4,604 & 0.99 & $0.87-1.12$ & 0.846 & 0.404 & 0.225 \\
\hline \multirow[t]{2}{*}{ TT vs. CC } & Premenopausal & 8 & 1,993 & 0.87 & $0.72-1.04$ & 0.136 & 0.458 & 0.204 \\
\hline & Postmenopausal & 9 & 3,110 & 0.94 & $0.82-1.09$ & 0.433 & 0.144 & 0.128 \\
\hline \multirow[t]{2}{*}{$\mathrm{TT}$ vs. $\mathrm{CT}+\mathrm{CC}$} & Premenopausal & 8 & 3,962 & 0.89 & $0.77-1.04$ & 0.135 & 0.138 & 0.227 \\
\hline & Postmenopausal & 9 & 6,182 & 0.95 & $0.85-1.07$ & 0.389 & 0.095 & 0.029 \\
\hline \multirow[t]{2}{*}{$\mathrm{CT}+\mathrm{TT}$ vs. CC } & Premenopausal & 9 & 5,475 & 0.89 & $0.77-1.03$ & 0.121 & 0.144 & 0.242 \\
\hline & Postmenopausal & 10 & 6,982 & 0.98 & $0.87-1.10$ & 0.706 & 0.929 & 0.381 \\
\hline
\end{tabular}

Table IV. Summary of the included studies in the survival analysis.

\begin{tabular}{|c|c|c|c|c|c|}
\hline Model & Variables & Studies, $\mathrm{n}$ & $\begin{array}{c}\text { Hazard ratio } \\
(95 \% \text { confidence interval) }\end{array}$ & P-value & I-squared, \% \\
\hline Dominant & $\begin{array}{l}\mathrm{CC} \\
\mathrm{CT} / \mathrm{TT}\end{array}$ & 3 & $\begin{array}{l}\text { Reference } \\
0.67(0.29-1.06)\end{array}$ & 0.001 & 51.6 \\
\hline Recessive & $\begin{array}{l}\mathrm{CC} / \mathrm{CT} \\
\mathrm{TT}\end{array}$ & 2 & $\begin{array}{l}\text { Reference } \\
1.00(0.10-1.90)\end{array}$ & 0.03 & 81.4 \\
\hline Homozygote & $\begin{array}{l}\mathrm{CC} \\
\mathrm{TT}\end{array}$ & 4 & $\begin{array}{l}\text { Reference } \\
1.06(0.45-1.68)\end{array}$ & 0.001 & 86.5 \\
\hline Heterozygote & $\begin{array}{l}\mathrm{CC} \\
\mathrm{CT}\end{array}$ & 2 & $\begin{array}{l}\text { Reference } \\
1.21(0.96-1.45)\end{array}$ & $<0.001$ & 0.0 \\
\hline Allelic & $\begin{array}{l}\mathrm{C} \\
\mathrm{T}\end{array}$ & 1 & $\begin{array}{l}\text { Reference } \\
1.06(0.94-1.20)\end{array}$ & - & - \\
\hline
\end{tabular}

which assumed the allele contrast model, two co-dominant models, one recessive model and one dominant model of the SOD2 rs4880 variant, respectively. Subgroup analyses were also conducted according to ethnicity and menopausal status using the ORs.

To assess the heterogeneity of the publications, Chi-square $\left(X^{2}\right)$ tests were carried out. At first, if I-squared $\leq 50 \%$, the ORs with $95 \%$ CI were calculated using the fixed effects model (Mantel-Haenszel) for meta-analysis (56). If I-squared $>50 \%$, the fixed effects model could not be applied, and so the random effects model (DerSimonian and Laird) was used (57). Conventionally, pooled $\mathrm{OR} \neq 1$ revealed the existent association between breast cancer risk and SOD2 gene polymorphism, and pooled $\mathrm{HR} \neq 1$ revealed association between cancer survival and polymorphism. If $95 \% \mathrm{CI}$ did not overlap $1, \mathrm{P}<0.05$ was considered to indicate a statistically significant difference. The pooled ORs and HRs with $95 \%$ CI were presented in the form of forest plots, using Stata version 12.0 (StataCorp LP, College Station, TX, USA).

To assess potential publication bias, graphical funnel plots were used, and Egger's and Begg's linear regression methods were also utilized to estimate the funnel plot asymmetry. An asymmetric funnel plot demonstrated possible publication bias and $\mathrm{P}<0.05$ was considered to indicate a statistically significant publication bias.

\section{Results}

Characteristics of the studies. Through the primary search algorithm, 189 publications were acquired, which consisted of 79 studies from PubMed or MEDLINE and 110 studies from EMBASE. Only 45 candidate studies were retrieved for more detailed evaluation. By reading the full texts, 11 studies were out of scope as they did not satisfy the inclusion criteria (one meeting abstract, three animal experiments or cell cultures and seven without available data). Finally, a total of 34 publications were available for the present meta-analysis, 26 for risk analysis (25-50) and eight for survival analysis (58-65). The flow chart of study search and inclusion was demonstrated in Fig. 1.

For the risk analysis, the 26 included studies were published between 1999 and 2015 and consisted of 18,481 cases and 19,527 controls. The total sample size of the patients was 38,008 , ranging from $187-9054$ per cohort. As an article had 


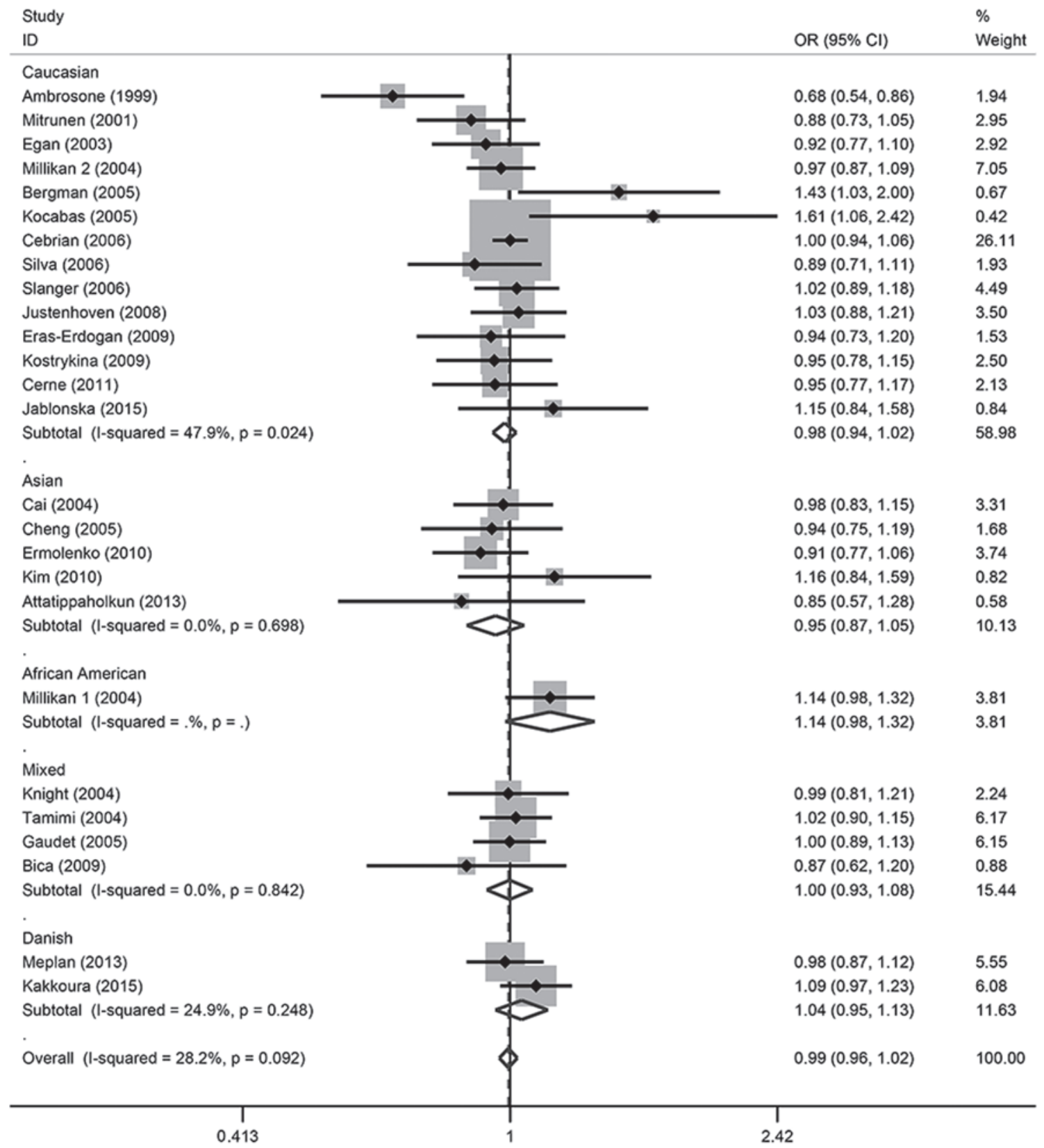

Figure 2. Forrest plots of OR for T vs. C. OR, odd ratio; CI, confidence interval.

two cohorts and ethnicities (30), there were 27 cohorts. A total of 14 were conducted in Caucasian patients, five in Asian patients, two in Danish patients, one in African American patients and four in mixed races. All of the case patients were confirmed by histological or pathological methods. The controls were healthy or free of breast cancer, and matched for age, ethnicity or area to cases. The majority of the cohorts examined the blood sample using polymerase chain reaction (PCR) genotyping methods. For the survival analysis, the included eight studies contained 5746 participants, published between 2005 and 2014. The primary characteristics of included cohorts were summarized in Table I.

\section{Data synthesis}

SOD2 polymorphism and risk analysis. To estimate the association between breast cancer risk and SOD2 gene polymorphism, the ORs and their corresponding 95\% CIs were reconstructed from the 27 cohorts. As demonstrated in Table II and Fig. 2, in all of the cohorts included in the present analysis, there were no significant relationships found in any of the genetic models. For the allele contrast, the wild-type allele did not increase or decrease the risk of breast cancer compared with the variant allele (T vs. C: OR, 0.99; 95\% CI, 0.96-1.02). There was no association between breast cancer risk and SOD2 gene polymorphism in two co-dominant models (CT vs. CC: OR, 1.00; 95\% CI, 0.95-1.05; TT vs. CC: OR, 0.98; 95\% CI, 0.92-1.05), one recessive model (TT vs. CT + CC: OR, 1.07; 95\% CI, 0.94-1.21) or one dominant model (CT + TT vs. CC: OR, 0.99; 95\% CI, 0.95-1.05).

In the subgroup analysis, there was also no significant association detected in different ethnicities or menopausal status, except for TT vs. CT + CC in Caucasian patients, 


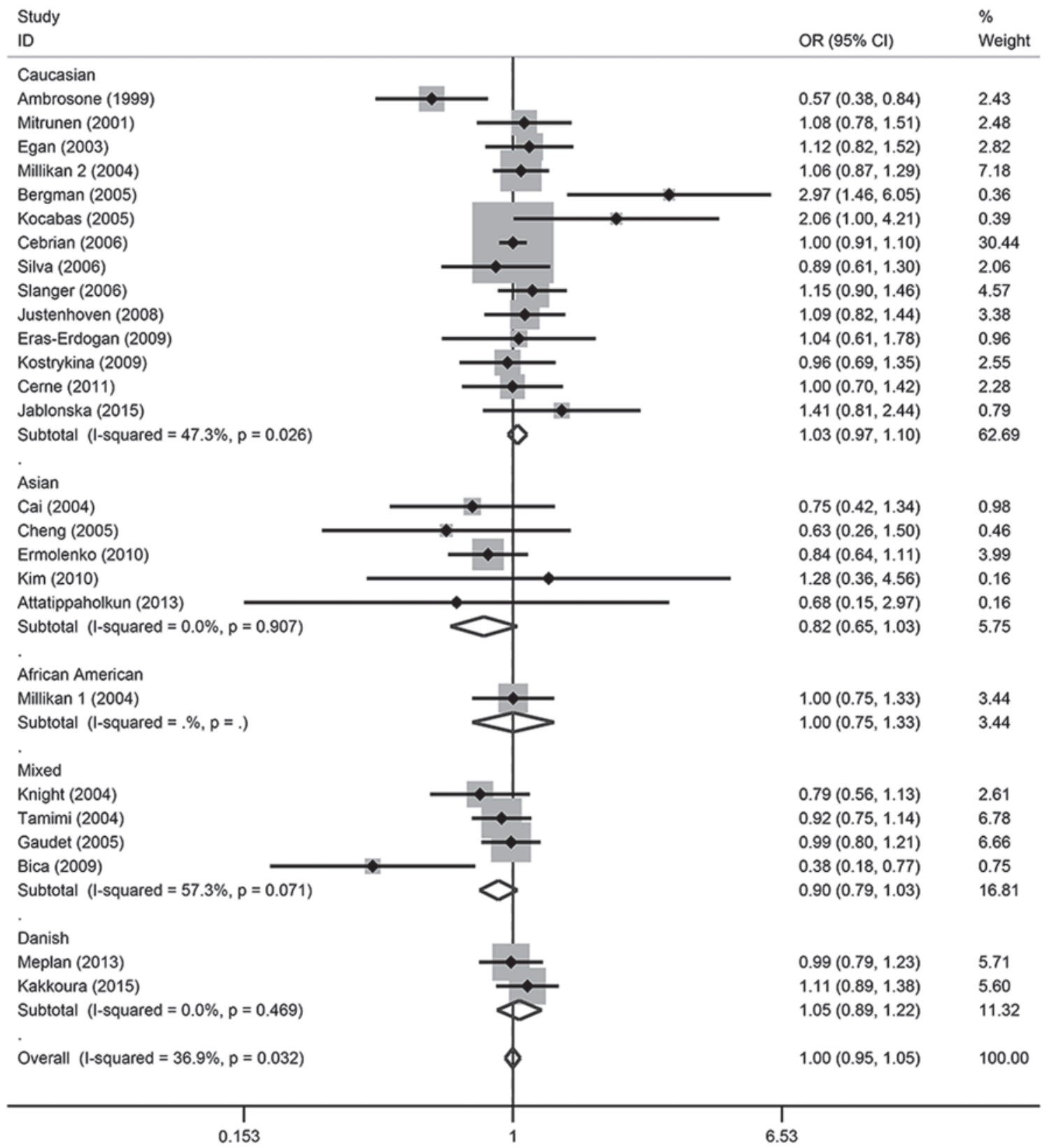

Figure 3. Forrest plots of OR for CT vs. CC. OR, odd ratio; CI, confidence interval.

which demonstrated a marginal association (OR, 0.94; 95\% CI, 0.88-1.00); however, this association was not significant $(\mathrm{P}>0.05)$. These details were listed in Tables II and III, and Figs. 2-6.

SOD2 polymorphism and survival analysis. No significant relationship was detected from the present meta-analysis, which included eight studies that investigated the association between SOD2 polymorphism and breast cancer overall survival (OS). There were no significant differences between patients with the T carrier and CC genotype (CT + TT vs. CC: HR, 0.67; 95\% CI, 0.29-1.06), or between TT and CC + CT genotype (TT vs. CT + CC: HR, 1.00; 95\% CI, 0.10-1.90). When compared with the CC genotype, it was not demonstrated that TT or CT genotypes had a better outcome (TT vs. CC: HR, 1.06; 95\% CI, 0.45-1.68; CT vs. CC: HR, 1.21; 95\% CI, 0.96-1.45). In addition, due to the limited number of included studies, only one cohort compared the T allele with $\mathrm{C}$ allele, so the OS could not be evaluated (Table IV).

Sensitivity analysis. Sensitivity analyses were carried out to determine whether there was association between breast cancer risk and SOD2 gene polymorphism. The inclusion criteria were altered to fit the Hardy-Weinberg equilibrium (HWE) and nine cohorts were excluded due to not meeting the HWE in the distribution of the genotype among the controls. However, all the ORs and corresponding 95\% CIs were not substantially altered, suggesting that the results were statistically robust (data not shown).

Bias analysis. To assess the potential publication bias, Egger's and Begg's linear regression methods were applied for this analysis. As demonstrated in Tables II and III, there was no evidence of statistically significant differences among the 


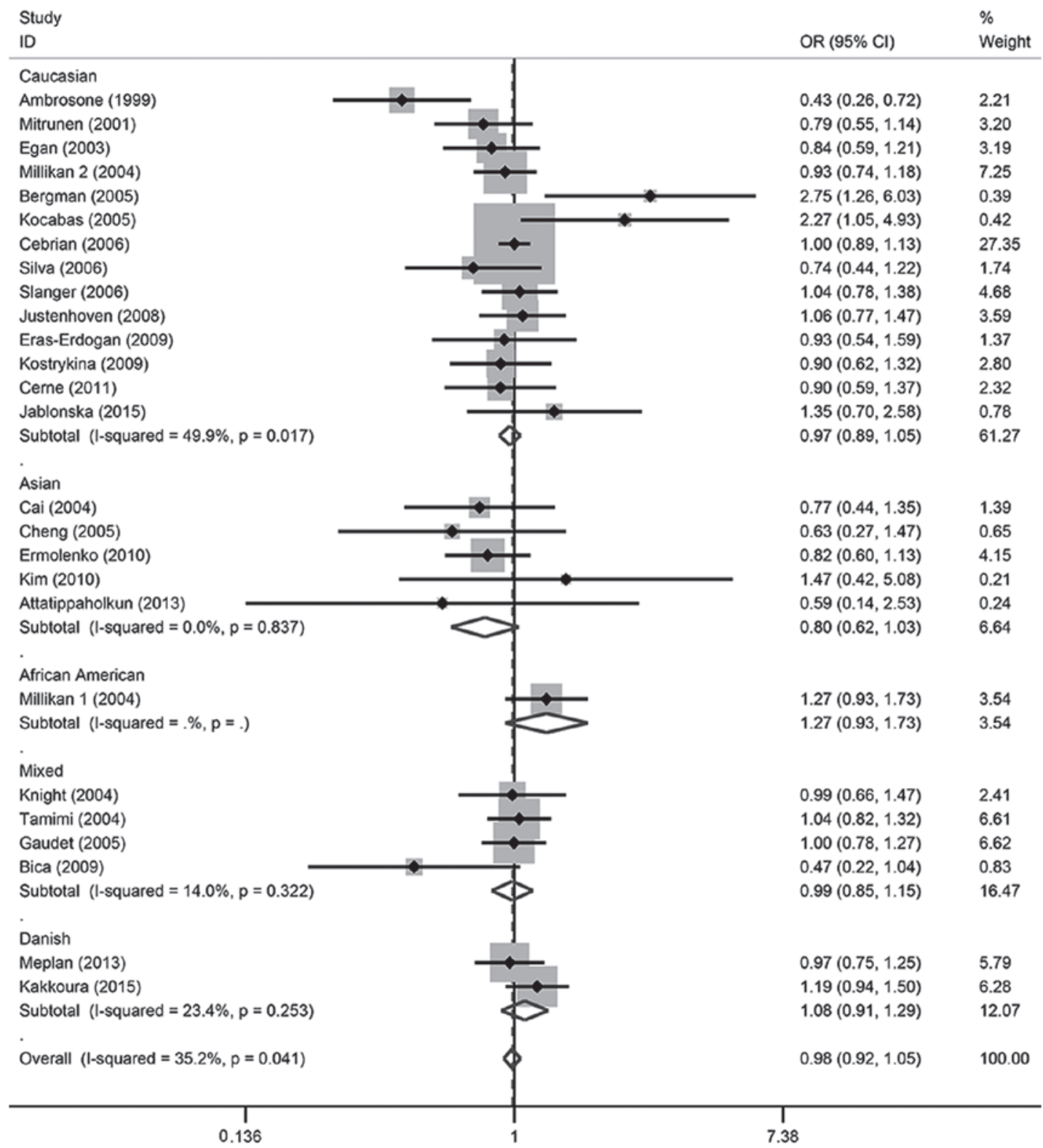

Figure 4. Forrest plots of OR for TT vs. CC. OR, odd ratio; CI, confidence interval.

whole analysis, except for the TT vs. CT + CC in the subgroup of postmenopausal status, which had a Begg's value of 0.029 but an Egger's value of 0.095 (Table III). However, this result had little impact on the present analysis.

\section{Discussion}

Due to the electron transport chain and environment exposure in mitochondrion, many ROS are formed as a by-product during cell metabolic or oxidative phosphorylation processes, such as hydrogen peroxide, superoxide anion radical and hydroxyl radical (66). As a very important part of the antioxidant defense system, SOD2 has a crucial role in balancing oxidant stress and ROS in mitochondria (67). In an animal experiment, a murine model with SOD2 gene deficiency demonstrated neurodegeneration, myocardial injury and perinatal death due to the impaired SOD2 activity (68). As a polymorphic enzyme, the SOD2 gene has a series of SNPs, such as Val-16Ala and Ile58Thr polymorphisms $(20,69)$, and the SNPs in the oxidative stress-related genes have some links with cancer risk (70). In a review, several studies demonstrated that, in cancer cells, the activity and expression of SOD2 was usually lower compared with the normal cells (71). Thus, various studies have focused on illuminating the association between SOD2 polymorphism and breast cancer; however, the results have remained controversial and uncertain.

In 1999, the first research reporting the relationship between SOD2 Val-16Ala polymorphism and breast cancer in a Caucasian population was conducted by Ambrosone et al (25), which drew a conclusion that SOD2 had a significant role in breast cancer risk, particularly in premenopausal women. More specifically, premenopausal women with homozygous CC demonstrated a 4-fold higher risk of developing breast cancer compared with heterozygote CT or homozygous TT (OR, 4.3; $95 \% \mathrm{CI}, 1.7-10.8)$. In 2005, Bergman et al (32) conducted a case-control study that included 118 women with early onset 


\begin{tabular}{|c|c|c|}
\hline $\begin{array}{l}\text { Study } \\
\text { ID }\end{array}$ & OR $(95 \% \mathrm{Cl})$ & $\begin{array}{l}\% \\
\text { Weight }\end{array}$ \\
\hline \multicolumn{3}{|l|}{ Caucasian } \\
\hline Ambrosone (1999) & $0.63(0.41,0.98)$ & 1.48 \\
\hline Mitrunen (2001) & $0.75(0.57,0.99)$ & 3.27 \\
\hline Egan (2003) & $0.78(0.58,1.05)$ & 2.86 \\
\hline Millikan 2 (2004) & $0.90(0.74,1.09)$ & 6.37 \\
\hline $1.18(0.70,2.01)$ & $1.18(0.70,2.01)$ & 0.72 \\
\hline Kocabas (2005) & $1.48(0.78,2.79)$ & 0.45 \\
\hline Cebrian (2006) & $1.00(0.90,1.11)$ & 21.74 \\
\hline Silva (2006) & $0.80(0.52,1.23)$ & 1.39 \\
\hline Slanger (2006) & $0.95(0.75,1.20)$ & 4.22 \\
\hline Justenhoven (2008) & $1.00(0.78,1.29)$ & 3.43 \\
\hline Eras-Erdogan (2009) & $0.90(0.64,1.25)$ & 2.14 \\
\hline Kostrykina (2009) & $0.93(0.68,1.26)$ & 2.47 \\
\hline Ceme (2011) & $0.90(0.64,1.28)$ & 1.94 \\
\hline Jablonska (2015) & $1.07(0.63,1.81)$ & 0.77 \\
\hline Subtotal (I-squared $=0.0 \%, p=0.484$ ) & $0.94(0.88,1.00)$ & 53.26 \\
\hline \multicolumn{3}{|l|}{. } \\
\hline \multicolumn{3}{|l|}{ Asian } \\
\hline Cai (2004) & $1.00(0.83,1.20)$ & 6.48 \\
\hline Cheng (2005) & $0.97(0.75,1.26)$ & 3.29 \\
\hline Ermolenko (2010) & $0.92(0.71,1.19)$ & 3.52 \\
\hline $\operatorname{Kim}(2010)$ & $1.16(0.82,1.65)$ & 1.66 \\
\hline Tsai (2012) & $1.76(1.20,2.59)$ & 1.12 \\
\hline Attatippaholkun (2013) & $0.84(0.52,1.37)$ & 1.04 \\
\hline Subtotal (I-squared $=47.5 \%, p=0.090)$ & $1.03(0.92,1.16)$ & 17.11 \\
\hline \multirow{2}{*}{\multicolumn{3}{|c|}{ African American }} \\
\hline & & \\
\hline Millikan 1 (2004) & $1.27(1.01,1.59)$ & 3.96 \\
\hline \multirow{2}{*}{\multicolumn{3}{|c|}{ Subtotal ( $1-$ squared $=. \%, p=$. ) }} \\
\hline & & \\
\hline \multicolumn{3}{|l|}{ Mixed } \\
\hline Knight (2004) & $1.15(0.83,1.59)$ & 1.97 \\
\hline Tamimi (2004) & $1.09(0.90,1.33)$ & 5.64 \\
\hline Gaudet (2005) & $1.01(0.83,1.23)$ & 5.64 \\
\hline Bica (2009) & $1.09(0.65,1.84)$ & 0.77 \\
\hline Subtotal (I-squared $=0.0 \%, p=0.896$ ) & $1.07(0.94,1.21)$ & 14.02 \\
\hline \multirow{2}{*}{\multicolumn{3}{|c|}{ Danish }} \\
\hline & & \\
\hline Meplan (2013) & $0.98(0.79,1.20)$ & 5.14 \\
\hline Kakkoura (2015) & $1.10(0.92,1.32)$ & 6.50 \\
\hline Subtotal $(1-$ squared $=0.0 \%, p=0.378$ ) & $1.05(0.91,1.20)$ & 11.65 \\
\hline \multicolumn{3}{|l|}{. } \\
\hline Overall (I-squared $=21.4 \%, p=0.160$ ) & $1.00(0.95,1.05)$ & 100.00 \\
\hline $\begin{array}{c}1 \\
0.358\end{array}$ & & \\
\hline
\end{tabular}

Figure 5. Forrest plots of OR for TT vs. CT + CC. OR, odd ratio; CI, confidence interval.

breast cancer and 174 age-matched controls, which indicated that SOD2 TT and CT genotype could increase the prevalence rate of breast cancer (OR, 2.7; 95\% CI, 2.2-5.5; OR, 3.0; 95\% CI, 1.4-6.5). In the same year, Kocabaş et al (35) also carried out another case-control study, including 103 patients and 84 controls, demonstrating a similar result to Bergman et al (32); however, no significant difference about the risk of allele $\mathrm{T}$ and $\mathrm{C}$ was observed. Furthermore, the majority of other publications suggested that the SOD2 Val-16Ala could not increase or decrease breast cancer risk and survival (26-31,33,34,36-50).

It is widely accepted that meta-analyses have been the gold standard to judge the association between risk factors and diseases (72). In 2008, Bag and Bag (51) conducted the first meta-analysis investigating the association between Val-16Ala and breast cancer, with 13 publications that included 7,366 cases and 9,102 controls. Their findings indicated no overall association with the Val-16Ala polymorphism (25). Two years later, Ma et al (53) and Qiu et al (55) conducted two independent meta-analyses, respectively, and obtained the same negative conclusion. Although the analysis of Qiu et al (55) involved 58,448 subjects of 26,022 cases and 32,426 controls, the patient resources of several case-control studies were mixed and unavailable at present. Subsequently, two relative meta-analyses were published in 2011 and 2012, but all of the included studies and cohorts were carried out before 2009 (52,54). From 2010-2016, there were another eight studies published, and so the present meta-analysis was conducted (43-50).

The present updated meta-analysis consisted of 18,481 cases and 19,527 controls from 27 cohorts or case-control studies for risk analysis and 5,746 cancer patients from eight studies for survival analysis. It aimed to more accurately estimate and investigate the association between the SOD2 Val-16Ala polymorphism and breast cancer risk or survival. From the present analysis, a marginal association between breast cancer risk and SOD polymorphism was demonstrated in terms of TT 


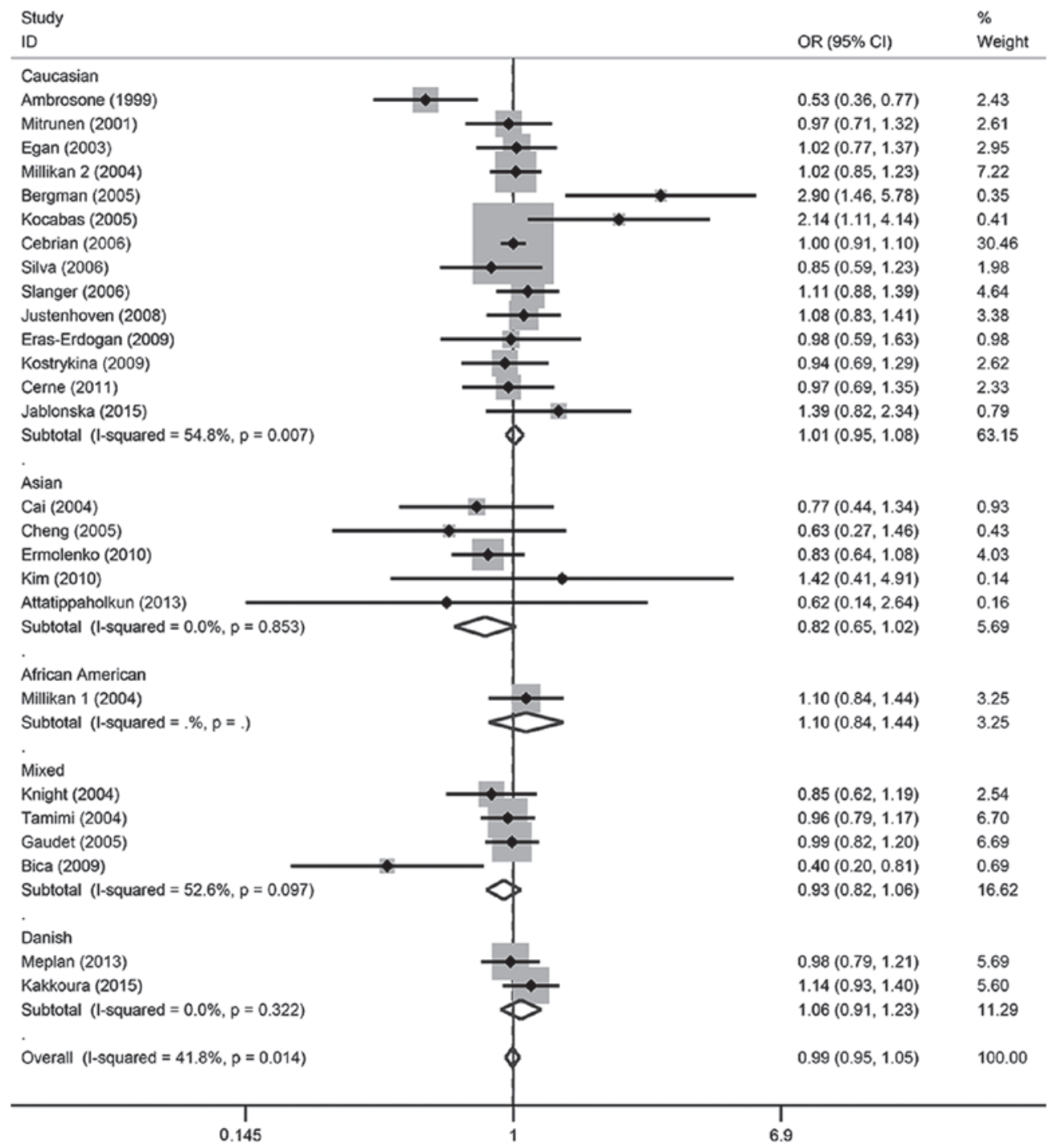

Figure 6. Forrest plots of OR for $\mathrm{CT}+\mathrm{TT}$ vs. CC. OR, odd ratio; CI, confidence interval.

vs. CT + CC genotype in Caucasian patients, which means the TT genotype may slightly decrease the risk of breast cancer compared with $\mathrm{CT}+\mathrm{CC}$. However, no other positive results were observed in the risk and survival analysis of breast cancer, which demonstrated no direct relationship between SOD2 polymorphism and breast cancer.

There were some limitations in the present meta-analysis. Given these, it is necessary to carefully analyze some considerable issues that may affect the study conclusion, to obtain a more cautious result. First, the quantity of the included studies cannot satisfy the condition of meta-analysis for the survival analysis, although every effort was made to search carefully on the PubMed and EMBASE databases with the various combinations of search terms by a computer-aided bibliographic technology. Therefore, the power about the SOD2 polymorphism and breast cancer survival may not be sufficient to make a statistical statement, and the conclusion is also limited, which requires more trails and larger sample sizes to clarify the relationship. Second, the included participants coming from hospital or population may have had some underlying diseases, which may influence the health of participants and the conclusion of the present study. For example, three studies had unclear expression about the underlying diseases in the controls $(29,35,43)$. There was no evidence of statistically significant publication bias according to the graphical funnel plots, and Egger's and Begg's linear regression methods; however, the potential bias cannot be ignored, and this may have affected the final conclusion. Only English publications were available and included in this meta-analysis and the rest were out of scope because the investigators could not understand the language. Last but not least, several different genotyping methods were applied in the studies used, such as PCR-restriction fragment length polymorphism, TaqMan and matrix-assisted laser desorption/ionization-time of flight mass spectrometry, which maybe make a difference to the present conclusion.

In conclusion, the present meta-analysis indicated that there was no significant relationship between SOD2 Val-16Ala polymorphism and breast cancer risk or survival, although in Caucasian patients, the SOD2 TT genotype may marginally decrease the risk of breast cancer in comparison to the $\mathrm{CT}+\mathrm{CC}$ genotype. Given this conclusion, more multicenter high-quality epidemiological studies or randomized controlled trials with a larger sample size should be conducted to clarify the association between the SOD2 Val-16Ala polymorphism and breast cancer risk or survival. 


\section{Acknowledgements}

The present study was supported by the National Natural Science Foundation of China (grant no. 81171320).

\section{References}

1. Torre LA, Bray F, Siegel RL, Ferlay J, Lortet-Tieulent J and Jemal A: Global cancer statistics, 2012. CA Cancer J Clin 65: 87-108, 2015

2. Hulka BS and Stark AT: Breast cancer: Cause and prevention. Lancet 346: 883-887, 1995.

3. Adami HO, Signorello LB and Trichopoulos D: Towards an understanding of breast cancer etiology. Semin Cancer Biol 8 : $255-262,1998$

4. DeBruin LS and Josephy PD: Perspectives on the chemical etiology of breast cancer. Environ Health Perspect 110 (Suppl) 119-128, 2002.

5. Lichtenstein P, Holm NV, Verkasalo PK, Iliadou A, Kaprio J, Koskenvuo M, Pukkala E, Skytthe A and Hemminki K: Environmental and heritable factors in the causation of cancer-analyses of cohorts of twins from Sweden, Denmark, and Finland. N Engl J Med 343: 78-85, 2000.

6. Tao Z, Shi A, Lu C, Song T, Zhang Z and Zhao J: Breast Cancer: Epidemiology and Etiology. Cell Biochem Biophys 72: 333-338, 2015.

7. Becuwe P, Ennen M, Klotz R, Barbieux C and Grandemange S: Manganese superoxide dismutase in breast cancer: From molecular mechanisms of gene regulation to biological and clinical significance. Free Radic Biol Med 77: 139-151, 2014.

8. Blokhina O, Virolainen E and Fagerstedt KV: Antioxidants, oxidative damage and oxygen deprivation stress: A review. Ann Bot 91: 179-194, 2003

9. Diao QX, Zhang JZ, Zhao T, Xue F, Gao F, Ma SM and Wang Y: Vitamin E promotes breast cancer cell proliferation by reducing ROS production and p53 expression. Eur Rev Med Pharmacol Sci 20: 2710-2717, 2016.

10. Paul S, Sengupta S, Bandyopadhyay TK and Bhattacharyya A: Stevioside induced ROS-mediated apoptosis through mitochondrial pathway in human breast cancer cell line MCF-7. Nutr Cancer 64: 1087-1094, 2012.

11. Ren G, Luo W, Sun W, Niu Y, Ma DL, Leung CH, Wang Y, $\mathrm{Lu} \mathrm{JJ}$ and Chen X: Psoralidin induced reactive oxygen species (ROS)-dependent DNA damage and protective autophagy mediated by NOX4 in breast cancer cells. Phytomedicine 23: 939-947, 2016.

12. Zhou Y, Shu F, Liang X, Chang H, Shi L, Peng X, Zhu J and Mi M: Ampelopsin induces cell growth inhibition and apoptosis in breast cancer cells through ROS generation and endoplasmic reticulum stress pathway. PLoS One 9: e89021, 2014.

13. Matés JM, Segura JA, Alonso FJ and Marquez J: Oxidative stress in apoptosis and cancer: An update. Arch Toxicol 86: 1649-1665, 2012.

14. Oberley TD and Oberley LW: Antioxidant enzyme levels in cancer. Histol Histopathol 12: 525-535, 1997.

15. Church SL, Grant JW, Meese EU and Trent JM: Sublocalization of the gene encoding manganese superoxide dismutase (MnSOD/SOD2) to $6 \mathrm{q} 25$ by fluorescence in situ hybridization and somatic cell hybrid mapping. Genomics 14: 823-825, 1992.

16. Creagan R, Tischfield J, Ricciuti F and Ruddle FH: Chromosome assignments of genes in man using mouse-human somatic cell hybrids: Mitochondrial superoxide dismutase (indophenol oxidase-B, tetrameric) to chromosome 6 . Humangenetik 20 203-209, 1973

17. Dhar SK and St Clair DK: Manganese superoxide dismutase regulation and cancer. Free Radic Biol Med 52: 2209-2222, 2012

18. Rosenblum JS, Gilula NB and Lerner RA: On signal sequence polymorphisms and diseases of distribution. Proc Natl Acad Sci USA 93: 4471-4473, 1996.

19. Crawford A, Fassett RG, Geraghty DP, Kunde DA, Ball MJ, Robertson IK and Coombes JS: Relationships between single nucleotide polymorphisms of antioxidant enzymes and disease. Gene 501: 89-103, 2012.

20. Shimoda-Matsubayashi S, Matsumine H, Kobayashi T, Nakagawa-Hattori Y, Shimizu Y and Mizuno Y: Structura dimorphism in the mitochondrial targeting sequence in the human manganese superoxide dismutase gene. A predictive evidence for conformational change to influence mitochondrial transport and a study of allelic association in Parkinson's disease. Biochem Biophys Res Commun 226: 561-565, 1996
21. Li X, Shen M, Cai H, Liu K, Liu Y, Huang Z, Liang C, Deng X, Ye J, Zou Q and Li J: Association between manganese superoxide dismutase (MnSOD) polymorphism and prostate cancer susceptibility: A meta-analysis. Int J Biol Markers 31: e422-430, 2016.

22. Mao C, Qiu LX, Zhan P, Xue K, Ding H, Du FB, Li J and Chen Q: MnSOD Val16Ala polymorphism and prostate cancer susceptibility: A meta-analysis involving 8,962 subjects. J Cancer Res Clin Oncol 136: 975-979, 2010.

23. Wang S, Wang F, Shi X, Dai J, Peng Y, Guo X, Wang X, Shen $\mathrm{H}$ and $\mathrm{Hu} \mathrm{Z}$ : Association between manganese superoxide dismutase (MnSOD) Val-9Ala polymorphism and cancer risk-A meta-analysis. Eur J Cancer 45: 2874-2881, 2009.

24. Kang SW: Superoxide dismutase 2 gene and cancer risk: Evidence from an updated meta-analysis. Int J Clin Exp Med 8: 14647-14655, 2015.

25. Ambrosone CB, Freudenheim JL, Thompson PA, Bowman E, Vena JE, Marshall JR, Graham S, Laughlin R, Nemoto T and Shields PG: Manganese superoxide dismutase (MnSOD) genetic polymorphisms, dietary antioxidants and risk of breast cancer. Cancer Res 59: 602-606, 1999.

26. Mitrunen K, Sillanpää P, Kataja V, Eskelinen M, Kosma VM, Benhamou S, Uusitupa M and Hirvonen A: Association between manganese superoxide dismutase (MnSOD) gene polymorphism and breast cancer risk. Carcinogenesis 22: 827-829, 2001

27. Egan KM, Thompson PA, Titus-Ernstoff L, Moore JH and Ambrosone CB: MnSOD polymorphism and breast cancer in a population-based case-control study. Cancer Lett 199: 27-33, 2003.

28. Cai Q, Shu XO, Wen W, Cheng JR, Dai Q, Gao YT and Zheng W: Genetic polymorphism in the manganese superoxide dismutase gene, antioxidant intake, and breast cancer risk: Results from the Shanghai Breast Cancer Study. Breast Cancer Res 6: R647-R655, 2004.

29. Knight JA, Onay UV, Wells S, Li H, Shi EJ, Andrulis IL and Ozcelik H: Genetic Variants of GPX1 and SOD2 and breast cancer risk at the ontario site of the breast cancer family registry. Cancer Epidemiol Biomarkers Prev 13: 146-149, 2004.

30. Millikan RC, Player J, de Cotret AR, Moorman P, Pittman G, Vannappagari V, Tse CK and Keku T: Manganese superoxide dismutase Ala-9Val polymorphism and risk of breast cancer in a population-based case-control study of African Americans and whites. Breast Cancer Res 6: R264-R274, 2004.

31. Tamimi RM, Hankinson SE, Spiegelman D, Colditz GA and Hunter DJ: Manganese superoxide dismutase polymorphism, plasma antioxidants, cigarette smoking and risk of breast cancer. Cancer Epidemiol Biomarkers Prev 13: 989-996, 2004.

32. Bergman M, Ahnström M, Palmebäck Wegman P and Wingren S: Polymorphism in the manganese superoxide dismutase (MnSOD) gene and risk of breast cancer in young women. J Cancer Res Clin Oncol 131: 439-444, 2005.

33. Cheng TC, Chen ST, Huang CS, Fu YP, Yu JC, Cheng CW, Wu PE and Shen CY: Breast cancer risk associated with genotype polymorphism of the catechol estrogen-metabolizing genes: A multigenic study on cancer susceptibility. Int J Cancer 113: 345-353, 2005.

34. Gaudet MM, Gammon MD, Santella RM, Britton JA, Teitelbaum SL, Eng SM, Terry MB, Bensen JT, Schroeder J, Olshan AF, et al: MnSOD Val-9Ala genotype, pro- and anti-oxidant environmental modifiers and breast cancer among women on Long Island, New York. Cancer Causes Control 16 1225-1234, 2005.

35. Kocabaş NA, Şardaş S, Cholerton S, Daly AK, Elhan AH and Karakaya AE: Genetic polymorphism of manganese superoxide dismutase (MnSOD) and breast cancer susceptibility. Cell Biochem Funct 23: 73-76, 2005.

36. Cebrian A, Pharoah PD, Ahmed S, Smith PL, Luccarini C, Luben R, Redman K, Munday H, Easton DF, Dunning AM and Ponder BA: Tagging single-nucleotide polymorphisms in antioxidant defense enzymes and susceptibility to breast cancer. Cancer Res 66: 1225-1233, 2006

37. Silva SN, Cabral MN, Bezerra de Castro G, Pires M, Azevedo AP, Manita I, Pina JE, Rueff J and Gaspar J: Breast cancer risk and polymorphisms in genes involved in metabolism of estrogens (CYP17, HSD17beta1, COMT and MnSOD): Possible protective role of MnSOD gene polymorphism Val/Ala and Ala/Ala in women that never breast fed. Oncol Rep 16: 781-788, 2006.

38. Slanger TE, Chang-Claude J and Wang-Gohrke S: Manganese superoxide dismutase Ala-9Val polymorphism, environmental modifiers, and risk of breast cancer in a German population. Cancer Causes Control 17: 1025-1031, 2006. 
39. Justenhoven C, Hamann U, Schubert F, Zapatka M, Pierl CB Rabstein S, Selinski S, Mueller T, Ickstadt K, Gilbert M, et al: Breast cancer: A candidate gene approach across the estrogen metabolic pathway. Breast Cancer Res Treat 108: 137-149, 2008.

40. Bica CG, De Moura Da Silva LL, Toscani NV, da Cruz IB, Sá G, Graudenz MS and Zettler CG: MnSOD gene polymorphism association with steroid-dependent cancer. Pathol Oncol Res 15: 19-24, 2009.

41. Eras-Erdogan N, Akbas E, Senli H, Kul S and Çolak T: Relationship between polymorphism in the manganese superoxide dismutase gene and breast cancer. Mutat Res 680: 7-11, 2009.

42. Kostrykina NA, Pechkovskiy EA, Boyarskikh UA, Sushko AG, Voronina EN, Lazarev AF, Petrova VD, Zarubina NA, Selezneva IA, Sinkina TV, et al: Associations of polymorphic variant of MnSOD gene with breast cancer in residents of the Altai Region. Bull Exp Biol Med 147: 84-87, 2009.

43. Ermolenko Kostrykina NA, Boyarskih UA, Voronina E, Sushko AG, Selezneva IA and Lazarew AF: Associations of polymorphisms in genes antioxidant enzymes and detoxification enzymes and breast cancer risk in residents of the west Siberian region. J Clinical Oncol 28: 2010.

44. Kim MK, Ahn SH, Son BH and Sung MK: Plasma antioxidant concentration, not superoxide dismutase polymorphism, is associated with breast cancer risk in Korean women. Nutr Res 30: 705-713, 2010

45. Cerne JZ, Pohar-Perme M, Novakovic S, Frkovic-Grazio S, Stegel V and Gersak K: Combined effect of CYP1B1, COMT, GSTP1, and MnSOD genotypes and risk of postmenopausal breast cancer. J Gynecol Oncol 22: 110-119, 2011.

46. Tsai SM, Wu SH, Hou MF, Chen YL, Ma H and Tsai LY: Oxidative stress-related enzyme gene polymorphisms and susceptibility to breast cancer in non-smoking, non-alcohol-consuming Taiwanese women: A case-control study. Ann Clin Biochem 49: $152-158,2012$.

47. Attatippaholkun W and Wikainapakul K: Predominant genotypes and alleles of two functional polymorphisms in the manganese superoxide dismutase gene are not associated with thai cervical or breast cancer. Asian Pac J Cancer Prev 14: 3955-3961, 2013.

48. Meplan C, Dragsted LO, Ravn-Haren G, Tjønneland A, Vogel U and Hesketh J: Association between polymorphisms in glutathione peroxidase and selenoprotein $\mathrm{P}$ genes, glutathione peroxidase activity, HRT use and breast cancer risk. PLoS One 8: e73316, 2013

49. Jablonska E, Gromadzinska J, Peplonska B, Fendler W, Reszka E, Krol MB, Wieczorek E, Bukowska A, Gresner P, Galicki M, et al: Lipid peroxidation and glutathione peroxidase activity relationship in breast cancer depends on functional polymorphism of GPX1. BMC Cancer 15: 657, 2015.

50. Kakkoura MG, Demetriou CA, Loizidou MA, Loucaides G, Neophytou I, Malas S, Kyriacou K and Hadjisavvas A: MnSOD and CAT polymorphisms modulate the effect of the Mediterranean diet on breast cancer risk among Greek-Cypriot women. Eur J Nutr 55: 1535-1544, 2016.

51. Bag A and Bag N: Target sequence polymorphism of human manganese superoxide dismutase gene and its association with cancer risk: A review. Cancer Epidemiol Biomarkers Prev 17: 3298-3305, 2008.

52. Liu G, Sun G, Wang Y, Wang D, Hu W and Zhang J: Association between manganese superoxide dismutase gene polymorphism and breast cancer risk: A meta-analysis of 17,842 subjects. Mol Med Rep 6: 797-804, 2012.

53. Ma X, Chen C, Xiong H, Fan J, Li Y, Lin H, Xu R, Huang G and $\mathrm{Xu}$ B: No association between SOD2 Val16Ala polymorphism and breast cancer susceptibility: A meta-analysis based on 9,710 cases and 11,041 controls. Breast Cancer Res Treat 122: 509-514, 2010

54. Chen Y and Pei J: Possible risk modifications in the association between MnSOD Ala-9Val polymorphism and breast cancer risk: Subgroup analysis and evidence-based sample size calculation for a future trial. Breast Cancer Res Treat 125: 495-504, 2011.

55. Qiu LX, Yao L, Mao C, Chen B, Zhan P, Yuan H, Xue K, Zhang $\mathrm{J}$ and $\mathrm{Hu} \mathrm{XC}$ : Lack of association between MnSOD Val16Ala polymorphism and breast cancer risk: A meta-analysis involving 58,448 subjects. Breast Cancer Res Treat 123: $543-547,2010$.
56. Mantel $\mathrm{N}$ and Haenszel W: Statistical aspects of the analysis of data from retrospective studies of disease. J Natl Cancer Inst 22: 719-748, 1959.

57. DerSimonian R and Laird N: Meta-analysis in clinical trials revisited. Contemp Clin Trials 45: 139-145, 2015.

58. Ambrosone CB, Ahn J, Singh KK, Rezaishiraz H, Furberg H, Sweeney C, Coles B and Trovato A: Polymorphisms in genes related to oxidative stress (MPO, MnSOD, CAT) and survival after treatment for breast cancer. Cancer Res 65: 1105-1111, 2005.

59. Udler M, Maia AT, Cebrian A, Brown C, Greenberg D, Shah M, Caldas C, Dunning A, Easton D, Ponder B and Pharoah P: Common germline genetic variation in antioxidant defense genes and survival after diagnosis of breast cancer. J Clin Oncol 25: 3015-3023, 2007.

60. Bewick MA, Conlon MSC and Lafrenie RM: Polymorphisms in manganese superoxide dismutase, myeloperoxidase and glutathione-S-transferase and survival after treatment for metastatic breast cancer. Breast Cancer Res Treat 111: 93-101, 2008.

61. Glynn SA, Boersma BJ, Howe TM, Edvardsen H, Geisler SB, Goodman JE, Ridnour LA, Lønning PE, Børresen-Dale AL, Naume B, et al: A mitochondrial target sequence polymorphism in manganese superoxide dismutase predicts inferior survival in breast cancer patients treated with cyclophosphamide. Clin Cancer Res 15: 4165-4173, 2009.

62. Yao S, Barlow WE, Albain KS, Choi JY, Zhao H, Livingston RB, Davis W, Rae JM, Yeh IT, Hutchins LF, et al: Manganese superoxide dismutase polymorphism, treatment-related toxicity and disease-free survival in SWOG 8897 clinical trial for breast cancer. Breast Cancer Res Treat 124: 433-439, 2010.

63. Hubackova M, Vaclavikova R, Ehrlichova M, Mrhalova M, Kodet R, Kubackova K, Vrána D, Gut I and Soucek P: Association of superoxide dismutases and $\mathrm{NAD}(\mathrm{P}) \mathrm{H}$ quinone oxidoreductases with prognosis of patients with breast carcinomas. Int J Cancer 130: 338-348, 2012.

64. Cronin-Fenton DP, Christensen M, Lash TL, Ahern TP, Pedersen L, Garne JP, Ewertz M, Autrup H, Sørensen HT and Hamilton-Dutoit S: Manganese superoxide dismutase and breast cancer recurrence: A Danish clinical registry-based case-control study and meta-analysis. PLoS One 9: e87450, 2014.

65. Tengström M, Mannermaa A, Kosma VM, Soini Y, Hirvonen A and Kataja V: MnSOD rs4880 and XPD rs13181 polymorphisms predict the survival of breast cancer patients treated with adjuvant tamoxifen. Acta Oncol 53: 769-775, 2014.

66. Sosa V, Moline T, Somoza R, Paciucci R, Kondoh H and LLeonart ME: Oxidative stress and cancer: An overview. Ageing Res Rev 12: 376-390, 2013.

67. Zelko IN, Mariani TJ and Folz RJ: Superoxide dismutase multigene family: A comparison of the CuZn-SOD (SOD1), Mn-SOD (SOD2), and EC-SOD (SOD3) gene structures, evolution, and expression. Free Radic Biol Med 33: 337-349, 2002.

68. Lebovitz RM, Zhang H, Vogel H, Cartwright J Jr, Dionne L, Lu N, Huang S and Matzuk MM: Neurodegeneration, myocardial injury, and perinatal death in mitochondrial superoxide dismutase-deficient mice. Proc Natl Acad Sci USA 93: 9782-9787, 1996.

69. Ho YS and Crapo JD: Isolation and characterization of complementary DNAs encoding human manganese-containing superoxide dismutase. FEBS Lett 229: 256-260, 1988.

70. Janicka A, Szymanska-Pasternak J and Bober J: Polymorphisms in the oxidative stress-related genes and cancer risk. Ann Acad Med Stetin 59: 18-28, 2013 (In Polish).

71. Oberley LW and Buettner GR: Role of superoxide dismutase in cancer: A review. Cancer Res 39: 1141-1149, 1979.

72. Stewart LA and Parmar MK: Meta-analysis of the literature or of individual patient data: Is there a difference? Lancet 341 : 418-422, 1993. 